\title{
Optimal use of tocilizumab for severe and critical COVID-19: a
}

\section{systematic review and meta-analysis [version 1; peer review: 1}

\section{approved, 2 approved with reservations]}

\author{
Cahyo Wibisono Nugroho1,2, Satriyo Dwi Suryantoro(iD1,2, Yuliasih Yuliasih1, \\ Alfian Nur Rosyid2,3, Tri Pudy Asmarawati (iD1,2, Lucky Andrianto2,4, \\ Herley Windo Setiawan²,3, Bagus Aulia Mahdi (D1, Choirina Windradi(iD1, \\ Esthiningrum Dewi Agustin (iD) 5, Jonny Karunia Fajar (iD6

\footnotetext{
2Universitas Airlangga Hospital, Surabaya, East Java, 60115, Indonesia

${ }^{3}$ Department of Pulmonology and Respiratory Medicine, Faculty of Medicine, Airlangga University, Surabaya, East Java, 60132 , Indonesia

${ }^{4}$ Department of Anesthesiology and Reanimation, Faculty of Medicine, Airlangga University, Surabaya, East Java, 60132, Indonesia

${ }^{5}$ Faculty of Medicine, Airlangga University, Surabaya, East Java, 60132, Indonesia

${ }^{6}$ Department of Internal Medicine, Faculty of Medicine, Brawijaya University, Malang, East Java, 65145, Indonesia
} \\ ${ }^{1}$ Department of Internal Medicine, Faculty of Medicine, Airlangga University, Surabaya, East Java, 60132, Indonesia
}

V1 First published: 04 Feb 2021, 10:73

https://doi.org/10.12688/f1000research.45046.1

Latest published: 04 Feb 2021, 10:73

https://doi.org/10.12688/f1000research.45046.1

\section{Abstract}

Background: Several studies have revealed the potential use of tocilizumab in treating COVID-19 since no therapy has yet been approved for COVID-19 pneumonia. Tocilizumab may provide clinical benefits for cytokine release syndrome in COVID-19 patients.

Methods: We searched for relevant studies in PubMed, Embase, Medline, and Cochrane published from March to October 2020 to evaluate optimal use and baseline criteria for administration of tocilizumab in severe and critically ill COVID-19 patients. Research involving patients with confirmed SARS-CoV-2 infection, treated with tocilizumab and compared with the standard of care (SOC) was included in this study. We conducted a systematic review to find data about the risks and benefits of tocilizumab and outcomes from different baseline criteria for administration of tocilizumab as a treatment for severe and critically ill COVID-19 patients.

Results: A total of 26 studies, consisting of 23 retrospective studies, one prospective study, and two randomised controlled trials with 2112 patients enrolled in the tocilizumab group and 6160 patients in the SOC group, were included in this meta-analysis. Compared to the SOC, tocilizumab showed benefits for all-cause mortality events and a shorter time until death after first intervention but showed no difference in hospital length of stay. Upon subgroup analysis, tocilizumab showed fewer all-cause mortality events when CRP level

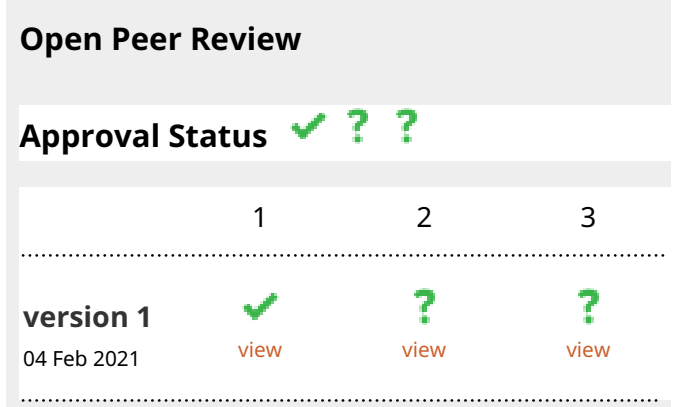

1. Lorenzo Cosmi, University of Florence,

Florence, Italy

2. Wiwien Heru Wiyono, Universitas Indonesia,

Jakarta, Indonesia

3. Zhongheng Zhang (Dir Run Run Shaw

Hospital, Zhejiang, China

Any reports and responses or comments on the article can be found at the end of the article. 
$\geq 100 \mathrm{mg} / \mathrm{L}, \mathrm{P} / \mathrm{F}$ ratio $200-300 \mathrm{mmHg}$, and $\mathrm{P} / \mathrm{F}$ ratio $<200 \mathrm{mmHg}$. However, tocilizumab showed a longer length of stay when CRP $<100$ $\mathrm{mg} / \mathrm{L}$ than the SOC.

Conclusion: This meta-analysis demonstrated that tocilizumab has a positive effect on all-cause mortality. It should be cautiously administrated for optimal results and tailored to the patient's eligibility criteria.

\section{Keywords}

Severe, critically ill, COVID-19, tocilizumab

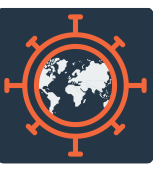

This article is included in the Emerging Diseases

and Outbreaks gateway.

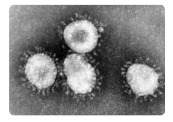

This article is included in the Coronavirus

collection.

Corresponding authors: Cahyo Wibisono Nugroho (dvdcwn@gmail.com), Satriyo Dwi Suryantoro (satriyo.dwi.suryantoro@fk.unair.ac.id)

Author roles: Nugroho CW: Conceptualization, Formal Analysis, Investigation, Methodology, Project Administration, Resources, Supervision, Validation, Writing - Original Draft Preparation, Writing - Review \& Editing; Suryantoro SD: Conceptualization, Formal Analysis, Investigation, Methodology, Resources, Supervision, Validation, Visualization, Writing - Original Draft Preparation, Writing Review \& Editing; Yuliasih Y: Formal Analysis, Supervision, Validation; Rosyid AN: Conceptualization, Investigation, Methodology, Software, Supervision, Validation, Writing - Original Draft Preparation; Asmarawati TP: Conceptualization, Formal Analysis, Investigation, Methodology, Project Administration, Software, Validation, Writing - Original Draft Preparation; Andrianto L: Formal Analysis, Investigation, Methodology, Project Administration, Resources, Software, Supervision, Validation, Visualization, Writing Original Draft Preparation; Setiawan HW: Conceptualization, Formal Analysis, Investigation, Methodology, Resources, Software, Supervision, Writing - Original Draft Preparation; Mahdi BA: Conceptualization, Data Curation, Formal Analysis, Investigation, Methodology, Project Administration, Resources, Software, Validation, Visualization, Writing - Original Draft Preparation, Writing Review \& Editing; Windradi C: Data Curation, Investigation, Methodology, Resources, Software, Validation, Visualization, Writing Original Draft Preparation, Writing - Review \& Editing; Agustin ED: Data Curation, Investigation, Methodology, Software, Visualization, Writing - Original Draft Preparation; Fajar JK: Conceptualization, Formal Analysis, Investigation, Methodology, Software, Supervision, Validation, Writing - Original Draft Preparation, Writing - Review \& Editing

Competing interests: No competing interests were disclosed.

Grant information: The author(s) declared that no grants were involved in supporting this work.

Copyright: @ 2021 Nugroho CW et al. This is an open access article distributed under the terms of the Creative Commons Attribution License, which permits unrestricted use, distribution, and reproduction in any medium, provided the original work is properly cited.

How to cite this article: Nugroho CW, Suryantoro SD, Yuliasih Y et al. Optimal use of tocilizumab for severe and critical COVID-19: a systematic review and meta-analysis [version 1; peer review: 1 approved, 2 approved with reservations] F1000Research 2021,10 :73 https://doi.org/10.12688/f1000research.45046.1

First published: 04 Feb 2021, 10:73 https://doi.org/10.12688/f1000research.45046.1 


\section{Introduction}

In December 2019, a novel virus named Severe Acute Respiratory Syndrome-Coronavirus-2 (SARS-CoV-2) that causes Coronavirus Disease-19 (COVID-19) began to spread worldwide and it become a pandemic globally ${ }^{1}$. COVID-19 manifestation ranges broadly from mild symptoms to severe illness. Several studies probed multiple types of inflammatory cytokine levels and found higher levels of interleukin (IL)-1 $\beta$, IL-1RA, IL-6, IL-7, IL-8, IL-10, IFN- $\gamma$, monocyte chemoattractant peptide-1, macrophage inflammatory protein (MIP)-1A, MIP-1B, granulocyte-colony stimulating factor, and tumor necrosis factor-alpha in severe COVID-19 patients ${ }^{2,3}$. COVID-19 causes severe illness due to activation of the cytokine cascade leading to cytokine release syndrome (CRS), which is delineated by systemic inflammation and multiple organ failure. Therefore, prompt strategies for treating CRS are essential for COVID-19 patients $^{3-5}$.

IL-6 is a proinflammatory cytokine that plays an essential role in CRS. Activation and secretion of IL- 6 by infected monocytes, macrophages, and dendritic cells cause two main effects; a plethora effect on immune cells and the innate immune system, and increased vascular permeability due to secretion of vascular endothelial growth factor (VEGF), resulting in hypotension and acute respiratory distress syndrome ${ }^{3,5,6}$.

Tocilizumab, a humanized monoclonal antibody interleukin6 receptor (IL-6R) inhibitor, is recommended by the National Health Commission of China for treating severe and critically ill patients with elevated IL-6 ${ }^{7}$. Recently, several case reports demonstrated tocilizumab could improve the clinical manifestations of seriously ill COVID-19 patients. Several retrospective case-control, single-armed studies and randomized clinical trials declared promising results of tocilizumab treatment in SARS CoV-2 infection. Nevertheless, some systematic reviews and meta-analyses showed an unclear risk of bias and reported debatable results about tocilizumab's benefit as a treatment ${ }^{6,8-13}$. We performed a systematic review and meta-analysis to research the risks and benefits of tocilizumab and investigate outcomes from different baseline criteria for administration of tocilizumab as a treatment for severe and critically ill COVID-19 patients.

\section{Methods}

\section{Study design}

We conducted a systematic review and meta-analysis to examine optimal use and baseline criteria for administration of treatment with tocilizumab versus standard of care (SOC) in severe and critically ill COVID-19 patients using data published March to October 2020. All-cause mortality events, length of stay in hospital, and days until death (time to death after first intervention) were measured to determine the risks and benefits of tocilizumab treatment. The baseline criteria for using tocilizumab included physical findings and markers of inflammation such as $\mathrm{C}$-reactive protein (CRP), $\mathrm{PaO} 2$ and $\mathrm{FiO} 2$ ratio (P/F ratio), lactate dehydrogenase (LDH), D-dimer, ferritin, IL-6, leucocyte, lymphocyte count, platelet count, and procalcitonin. We performed screening of several medical databases (PubMed,
Embase, Medline, and Cochrane) to collect data and calculate the risk ratio (RR) and $95 \%$ confidence intervals $(95 \% \mathrm{CI}$ ). This study used similar methods for the systematic review and meta-analysis to a previous study ${ }^{14}$, and was reported according to the Preferred Reporting Items for Systematic Review and Meta-Analysis (PRISMA) guidelines accessed from the PRISMA website ${ }^{15}$.

\section{Literature search}

The search strategy ${ }^{16}$, using medical subject headings (MeSH) terms, involved the use of a combination of the following keywords: (tocilizumab) OR (anti-IL-6 monoclonal antibody) OR (IL-6 blockade) OR (IL-6 receptor antagonist) AND severe AND critical ill AND (COVID-19) OR (novel coronavirus disease) OR (SARS-CoV-2). The search was performed by two authors (BAM and $\mathrm{CW}$ ) in PubMed, Embase, Medline, and Cochrane (March $1^{\text {st }}$ to October $31^{\text {st }} 2020$, last searched $2^{\text {nd }}$ November 2020) and the language was limited to English. We selected 606 full text and free full text articles from PubMed, included all article types, then we excluded them based on the exclusion criteria of case reports, reviews, editorials, letters, duplicate records, and studies with incomplete data. From filter selection of clinical trials, meta analyses, randomized control trials and systematic reviews within one year we got 42 articles after removing 655 articles (see Figure 1).

\section{Selection criteria}

The studies in the three searched databases were included based on the following criteria: (1) patient confirmed for SARS-CoV-2 infection; (2) patients treated with tocilizumab and compared with the SOC; and (3) complete data were provided for clinical outcomes. Exclusion criteria were (1) case reports, reviews, editorials, and letters; (2) duplicate records; and (3) studies with incomplete data.

\section{Data extraction and quality assessment}

All articles that qualified for inclusion according to the selection criteria were included in the analysis. Two independent investigators conducted the study assessment (BAM and CW). Two authors (BAM and EA) extracted necessary data from each included study including: first author, publication year, sample size, gender, baseline criteria for administration for tocilizumab, clinical outcomes of tocilizumab group and SOC group. Another consultant resolved any disagreement between the two investigators' findings (ANR and TPA).

\section{The methodological quality assessment}

We performed a methodological quality assesment of the article using the Newcastle-Ottawa Scale (NOS) before study inclusion. NOS comprises several items including: patient selection (4 points), comparability of the groups ( 2 points), and ascertainment of exposure ( 3 points). Each study was interpreted to be low quality (scores $<4$ ), moderate quality (scores of 5-6), or high quality (scores $\geq 7)^{17}$. We only included moderate to high quality articles in the analysis. The study assessment was conducted by two independent investigators (CW and EA) using a pilot form. Another consultant resolved any disagreement between the two investigators' findings (CWN and SDS). 


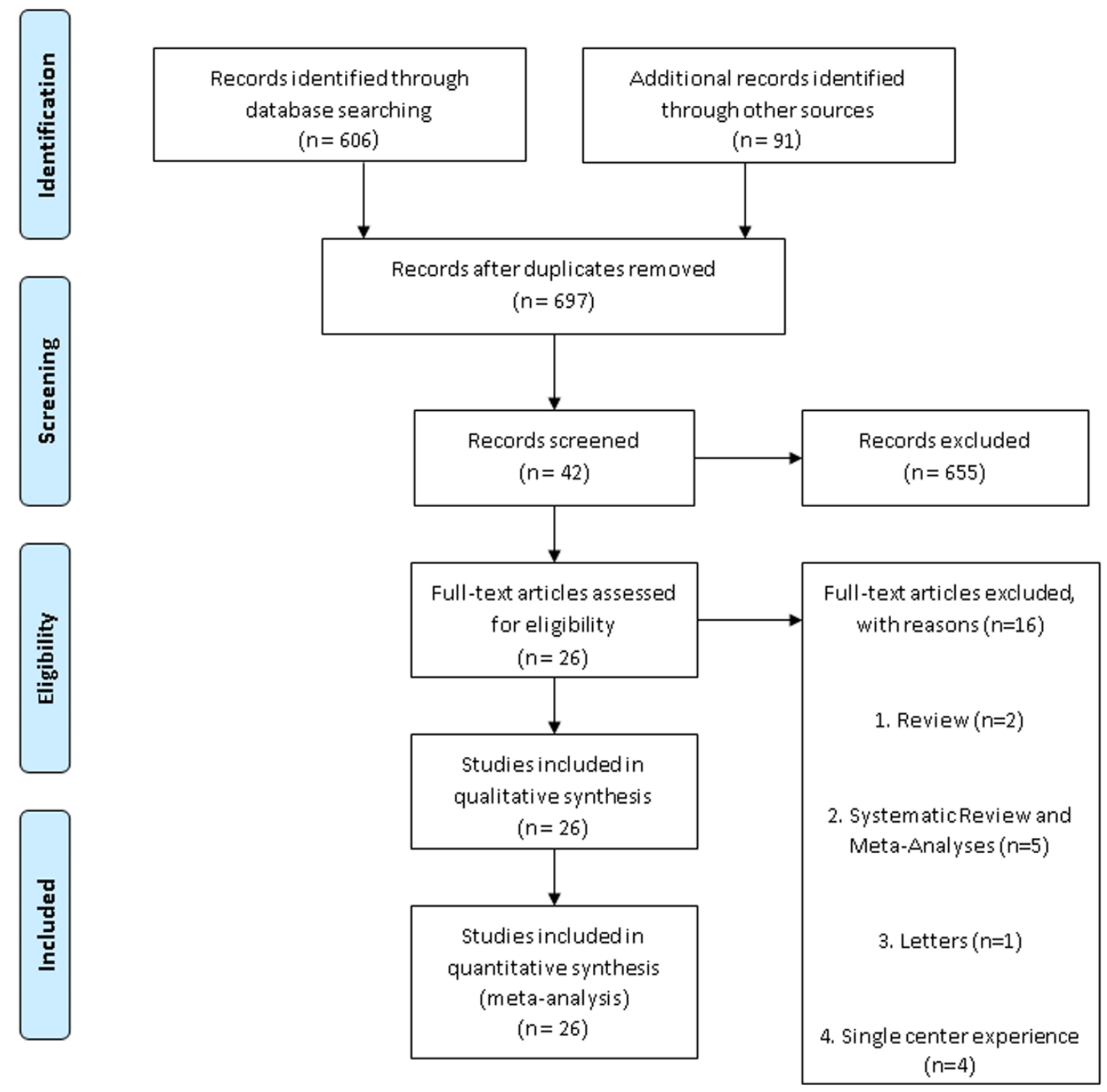

Figure 1. Study selection.

\section{Outcomes}

The study outcomes were all-cause mortality events, length of stay in hospital, and days until death (time to death after first intervention), comparing SOC and tocilizumab. We performed subgroup analysis for those outcomes based on CRP level $>100 \mathrm{mg} / \mathrm{L}$, CRP level <100 mg/L, $\mathrm{PaO}_{2}: \mathrm{FiO}_{2}$ ratio (P/F ratio) 200-300 mmHg, and $\mathrm{PaO}_{2}: \mathrm{FiO}_{2}(\mathrm{P} / \mathrm{F}$ ratio) $<200 \mathrm{mmHg}$.

\section{Statistical analysis}

Data were synthesized using RRs and mean differences (MDs), with 95\% CIs. Significance of RRs was determined using the $\mathrm{Z}$ test $(\mathrm{p}<0.05$ was considered statistically significant).
They were assessed for heterogeneity and possibility of publication bias before calculating significancy. We used the $\mathrm{Q}$ test for evaluating the heterogeneity among the included studies. A random effect model was used if heterogeneity existed $(\mathrm{p}<0.10)$; if not, a fixed-effect model was adopted. For publication bias, we used Egger's test and a funnel plot $(\mathrm{p}<0.05$ was considered statistically significant).

We analyzed the data with Review Manager (RevMan, Cochrane, London, UK) version 5.4.1. Two authors (BAM and JKF) conducted statistical analysis and presented the results in a forest plot. 


\section{Results}

Qualifying studies

We obtained 697 qualifying studies, 655 of which were excluded after examining the titles and abstracts. We performed a review of the complete texts for 42 potential studies and 16 studies were then excluded because they were reviews $(n=2)$; systematic review and meta-analyses $(n=5)$; letters $(n=1)$; single-center experiences $(n=4)$; case reports $(n=1)$; brief papers $(n=1)$ or had incomplete data $(n=2)$. Eventually, 26 papers met the inclusion criteria for our meta-analysis; these results are summarized in Figure 1. The characteristics of studies are described in Table 1. We have summarized the results of the outcomes in Table 2.

\section{Outcomes of tocilizumab treatment}

There is a significant difference between the SOC group and tocilizumab group (RR: $1.65 ; 95 \% \mathrm{CI}=1.37,2.00$ ) from all-cause mortality events (Figure 2) and days until death (time to death after first intervention) (MD: 6.03; 95\% CI: 0.31, 11.76). There is no significant difference between the length of stay (MD: -2.05 ; 95\% CI: $-5.25,1.16$ ). All outcomes showed evidence of heterogeneity and the random effect model was adopted.

\section{Subgroup analysis}

There is a significant difference in all-cause mortality events for patients with CRP level $>100 \mathrm{mg} / \mathrm{L}$ (RR: $1.78 ; 95 \% \mathrm{CI}: 1.35$, 2.34); P/F ratio $200-300 \mathrm{mmHg}$ (RR: 1.84 ; 95\% CI: $1.35,2.50$ ); and $\mathrm{P} / \mathrm{F}$ ratio $<200 \mathrm{mmHg}$ (RR: $1.44 ; 95 \% \mathrm{CI}: 1.28,1.63$ ). For length of stay in hospital, CRP level $<100 \mathrm{mg} / \mathrm{L}$ showed a significant difference (MD: $-7.75 ; 95 \%$ CI: $-10.31,-5.20$ ) (Figure 3).

Within the subgroup analysis, evidence of homogeneity was found and we used the fixed effect model for all-cause mortality events for $\mathrm{P} / \mathrm{F}$ ratio $<200 \mathrm{mmHg}$ and length of stay for CRP level $\geq 100 \mathrm{mg} / \mathrm{L}, \mathrm{CRP}$ level $<100 \mathrm{mg} / \mathrm{L}$, and P/F ratio $200-300 \mathrm{mmHg}$. The other parameters were analyzed using the random effect model.

\section{Analysis of publication bias}

We assessed the possibility of publication bias using Egger's test. There was no indication of publication bias $(\mathrm{p}<0.05)$ for all outcomes.

\section{Discussion}

To the best of our knowledge, this is the first meta-analysis investigating the optimal use of tocilizumab in severe and critically ill COVID-19 patients. The 26 studies analysed, mostly retrospective studies with only two clinical trials (Salvarini et al. and Somerset al.), suggest that treatment with tocilizumab gives fewer all-cause mortality events than the $\mathrm{SOC}^{17-42}$. Lan et al. showed that tocilizumab could not provide additional benefits for clinical outcomes of severe COVID-19, but the mortality rate was lower than the SOC, although this was not statistically different ${ }^{10}$. Studies from Kaye et al., Zhao, J et al., and Zhao, $\mathrm{M}$ et al., reported that tocilizumab showed a statistically significant reduction in mortality and fatality than the SOC, similar to our results ${ }^{9,11,13}$.

Nevertheless, hospital and ICU lengths of stay did not differ between tocilizumab and SOC $^{20-26,31,32,35,40,43}$. Only one study (Eimer et al.) showed that length of stay in hospital on tocilizumab was shorter than the SOC and it was able to shorten the duration of use of a ventilator. However, for the variable days until death, intervention with tocilizumab resulted in a shorter duration until death than the SOC due to secondary infections after tocilizumab treatment ${ }^{20}$.

Selection criteria from included studies for using tocilizumab treatment for COVID-19 mostly included similiar clinical manifestations but baseline laboratory parameters varied. Clinical manifestations for tocilizumab treatment eligibility were frequency of respiration $\geq 30$ breaths/min and peripheral capillary oxygen saturation $(\mathrm{SpO} 2)<93 \%$ while breathing ambient air. Laboratory markers for tocilizumab treatment eligiblity were $\mathrm{P} / \mathrm{F}$ ratio, CRP, ferritin, LDH and IL-6. In most studies, baseline criteria for administration of tocilizumab were level of $\mathrm{CRP} \geq 100 \mathrm{mg} / \mathrm{L}$ (normal values $<6 \mathrm{mg} / \mathrm{L}$ ), ferritin $\geq 900 \mathrm{ng} / \mathrm{mL}$ (normal value $<400 \mathrm{ng} / \mathrm{mL}$ ), $\mathrm{LDH}>220 \mathrm{U} / \mathrm{L}$, and $\mathrm{P} / \mathrm{R}$ ratio 200-300 mmHg $18-20,24,36,39,40,42$. .However, several studies used baseline criteria for administration of tocilizumab of CRP $<100 \mathrm{mg} / \mathrm{L}$ and $\mathrm{P} / \mathrm{F}$ ratio $<200 \mathrm{mmHg}^{23,30-34,36,43,44}$.

The SMACORE study used baseline criteria for administration of tocilizumab of CRP $>50 \mathrm{mg} / \mathrm{l}$, procalcitonin $<0.5 \mathrm{ng} / \mathrm{mL}$ and $\mathrm{P} / \mathrm{F}$ ratio $<300 \mathrm{mmHg}$ in seriously ill COVID-19 patients. Tocilizumab was first administered at $8 \mathrm{mg} / \mathrm{kg}$ (up to a maximum $800 \mathrm{mg}$ per dose) intravenously, repeated after 12 hours if no side effects were reported after the first dose. The result from this study was that tocilizumab administration did not reduce mortality rate or ICU admissions ${ }^{23}$.

Similar selection criteria were used by Masia et al.; the eligible participants had CRP $>50 \mathrm{mg} / \mathrm{l}$ and tocilizumab was given at an initial dose of $600 \mathrm{mg}$ intravenously for a weight of $>75 \mathrm{~kg}$ or $400 \mathrm{mg}$ when the weight was $<75 \mathrm{~kg}$. If their condition worsened, treatment was reevaluated following 24 hours. A second dose of tocilizumab (400 mg) was given if there was no clinical response. The result from this study was that tocilizumab administration significantly reduced the mortality rate $^{32}$.

In the randomized trial by Salvarini et al., the selection criteria for tocilizumab treatment were $\mathrm{P} / \mathrm{F}$ ratio of $200-300 \mathrm{mmHg}$. Tocilizumab was given intravenously at a starting dose of $8 \mathrm{mg} / \mathrm{kg}$ until $800 \mathrm{mg}$ within eight hours of randomization, and a second dose administered after 12 hours. This study showed no benefit on disease progression in the tocilizumab group compared with the SOC group ${ }^{42}$. 


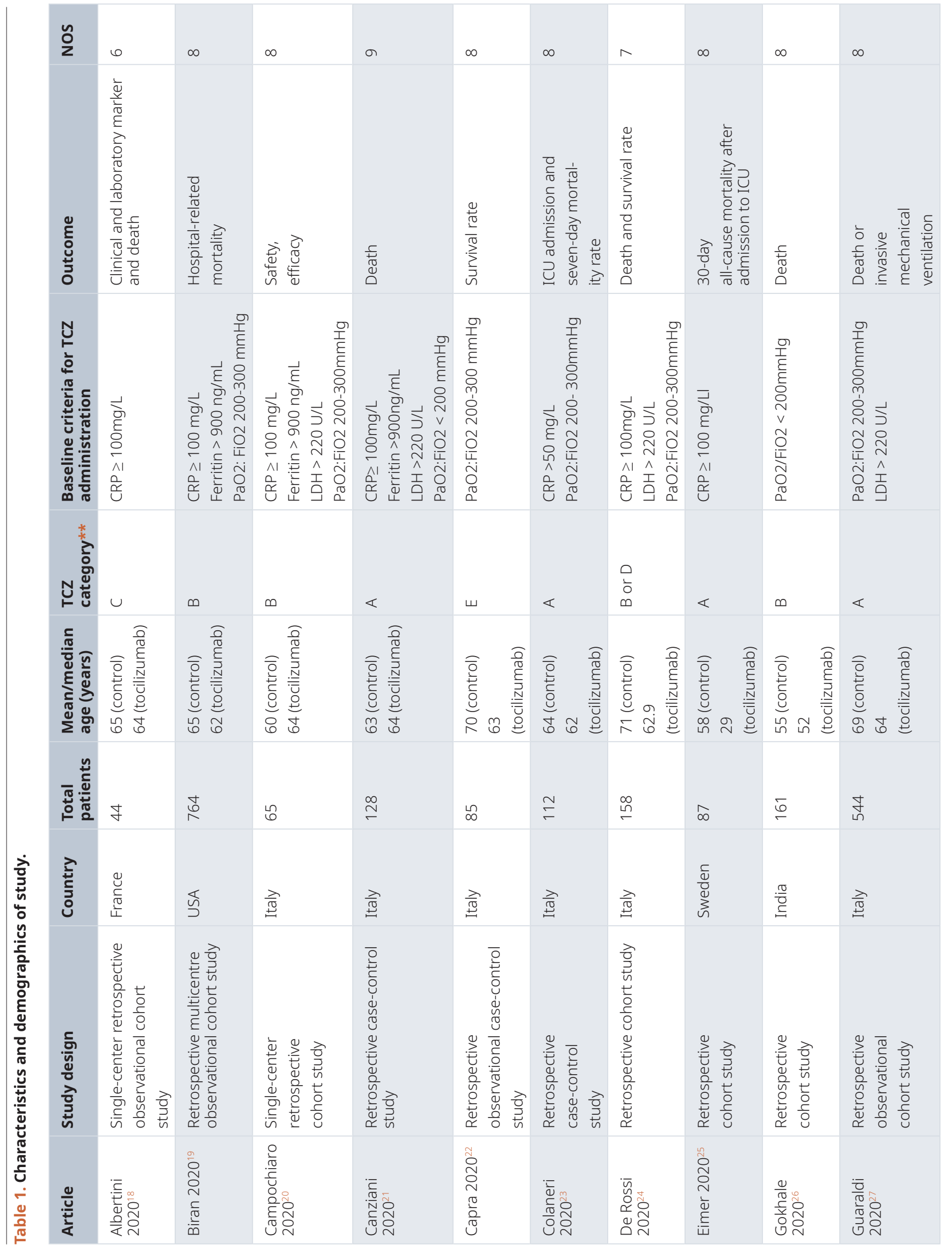




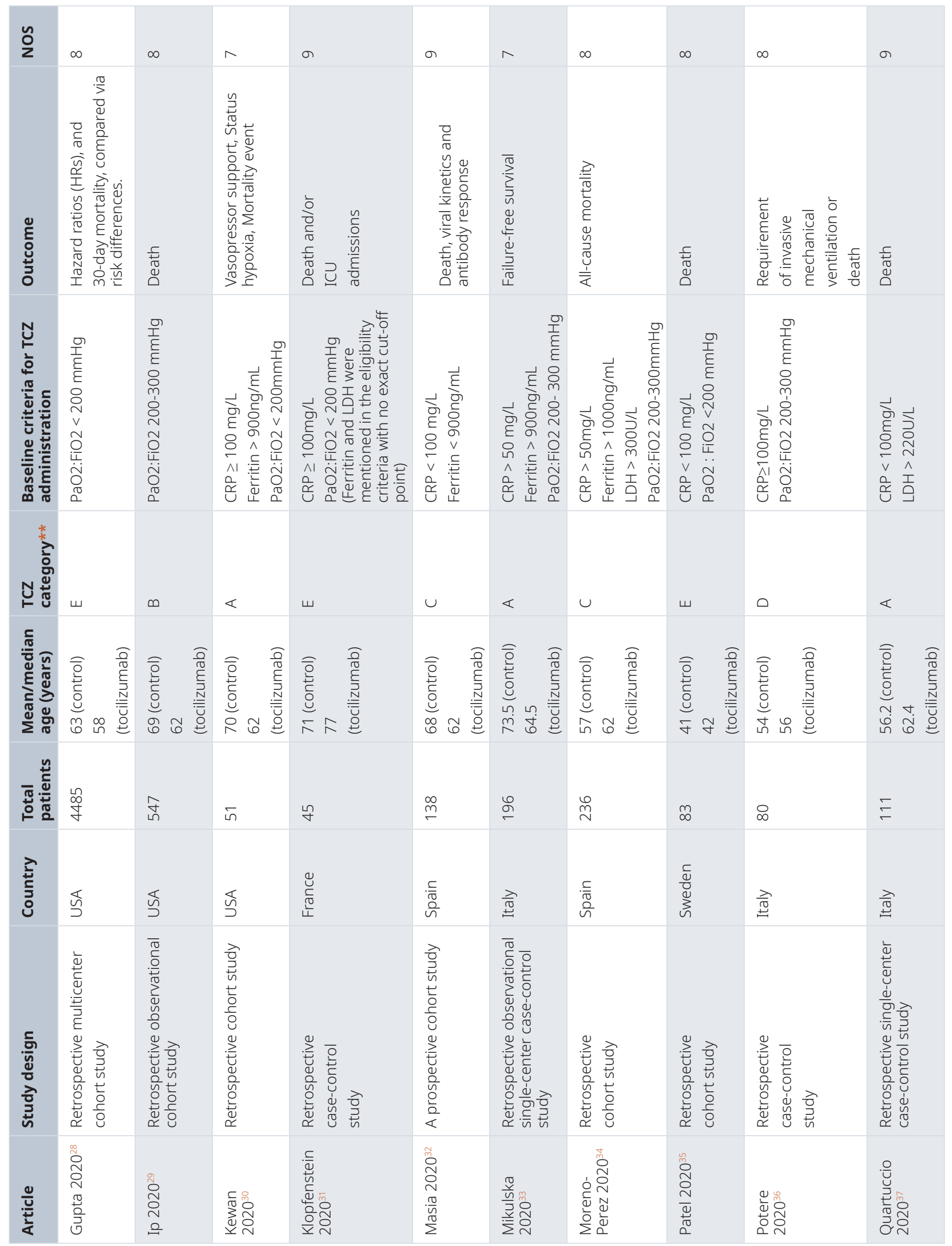




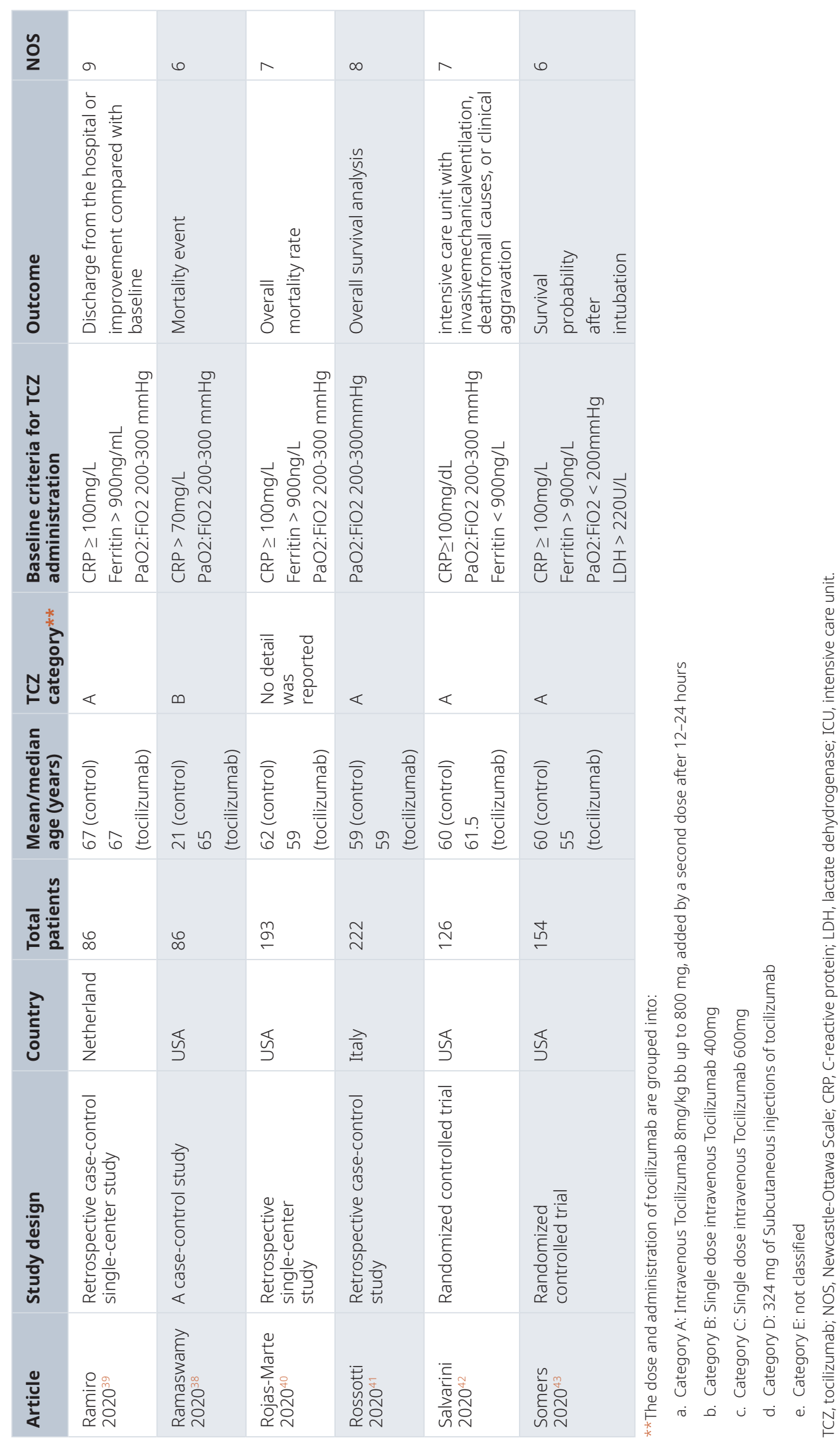


Table 2. Outcome and laboratory marker Tocilizumab group and standard of care group.

\begin{tabular}{|c|c|c|c|c|c|c|c|c|c|c|c|}
\hline \multirow{3}{*}{ Outcomes } & \multirow{3}{*}{$\mathbf{N}$} & \multirow{3}{*}{ Mode } & \multicolumn{4}{|c|}{ Value } & \multirow{3}{*}{$\mathrm{pE}$} & \multirow{3}{*}{ pHet } & \multirow{3}{*}{$\mathbf{P}$} & \multirow{3}{*}{$\mathbf{R R}$} & \multirow{3}{*}{$95 \%$ CI } \\
\hline & & & \multicolumn{2}{|c|}{ soc } & \multicolumn{2}{|c|}{ TCZ } & & & & & \\
\hline & & & $\mathbf{n}$ & Total & $n$ & Total & & & & & \\
\hline All-cause mortality & 26 & Random & 2475 & 61160 & 523 & 2112 & 0.2500 & $<0.00001$ & $<0.00001$ & 1.65 & $1.37,2.00$ \\
\hline \multicolumn{12}{|l|}{ Subgroup Analysis } \\
\hline $\mathrm{CRP}>100 \mathrm{mg} / \mathrm{L}$ & 13 & Random & 508 & 1114 & 234 & 894 & 0.1400 & 0.001 & $<0.0001$ & 1.71 & $1.30,2.24$ \\
\hline $\mathrm{CRP}<100 \mathrm{mg} / \mathrm{L}$ & 7 & Random & 83 & 512 & 28 & 266 & 0.4500 & $<0.0001$ & 0.8900 & 1.19 & $0.39,3.59$ \\
\hline P/F ratio $200-300$ mmHg & 15 & Random & 880 & 2137 & 296 & 1208 & 0.1300 & $<0.00001$ & 0.0001 & 1.84 & $1.35,2.50$ \\
\hline \multirow[t]{3}{*}{$\mathrm{P} /$ F ratio $<200 \mathrm{mmHg}$} & 8 & Fixed & 1576 & 3829 & 220 & 722 & 0.6600 & 0.8400 & $<0.00001$ & 1.44 & $1.28,1.63$ \\
\hline & \multirow{2}{*}{$N$} & \multirow{2}{*}{ Mode } & \multicolumn{4}{|c|}{ Value } & \multirow{2}{*}{$\mathrm{pE}$} & \multirow{2}{*}{ pHet } & \multirow{2}{*}{$P$} & \multirow{2}{*}{ MD } & \multirow{2}{*}{$95 \%$ CI } \\
\hline & & & \multicolumn{2}{|c|}{ SOC } & \multicolumn{2}{|c|}{$\mathrm{TCZ}$} & & & & & \\
\hline Length of stay (d) & 11 & Random & 14.22 & \pm 3.21 & 16.8 & $1 \pm 2.25$ & 0.5300 & $<0.00001$ & 0.21 & -2.05 & $-5.25,1.16$ \\
\hline \multicolumn{12}{|l|}{ Subgroup Analysis } \\
\hline $\mathrm{CRP}>100 \mathrm{mg} / \mathrm{L}$ & 8 & Fixed & \multicolumn{2}{|c|}{$16.02 \pm 3.86$} & \multicolumn{2}{|c|}{$16.35 \pm 3.19$} & 0.4800 & 0.7300 & 0.18 & 1.17 & $-0.54,2.88$ \\
\hline$C R P<100 \mathrm{mg} / \mathrm{L}$ & 3 & Fixed & \multicolumn{2}{|c|}{$10.17 \pm 1.97$} & \multicolumn{2}{|c|}{$18.77 \pm 1.18$} & 0.8500 & 0.8700 & $<0.00001$ & -7.75 & $-10.31,-5.20$ \\
\hline P/F ratio $200-300$ mmHg & 3 & Fixed & \multicolumn{2}{|c|}{$14.28 \pm 2.73$} & \multicolumn{2}{|c|}{$14.28 \pm 1.53$} & 0.8800 & 0.3700 & 0.30 & 1.15 & $-1.02,3.31$ \\
\hline $\mathrm{P} / \mathrm{F}$ ratio $<200 \mathrm{mmHg}$ & 7 & Random & \multicolumn{2}{|c|}{$15.36 \pm 5.73$} & \multicolumn{2}{|c|}{$18.74 \pm 2,23$} & 0.7300 & 0.0007 & 0.33 & -2.38 & $-7.19,2.44$ \\
\hline Days of death $(\mathrm{d})$ & 4 & Random & \multicolumn{2}{|c|}{$13.32 \pm 3.33$} & \multicolumn{2}{|c|}{$6.89 \pm 6.52$} & 0.1200 & $<0.00001$ & 0.04 & 6.03 & $0.31,11.76$ \\
\hline
\end{tabular}

Note, data were presents as mean \pm SD or $n$ [\%], SOC, Standard of care; TCZ, tocilizumab; N, number of studies; CRP, C-reactive protein; RR, relative risk; MD, mean difference; $\mathrm{pE}$, p Egger; PHet, $\mathrm{p}$ Heterogeneity; $\mathrm{CI}$, confidence interval.

According to the Moreno-Perez study, candidates for tocilizumab treatment had poor prognostic factors or worsening disease. One of indication for worsening condition was CRP level $>100 \mathrm{mg} / \mathrm{L}$ or $\mathrm{P} / \mathrm{F}$ ratio $<200 \mathrm{mmHg}^{34}$.

Our subgroup analysis showed tocilizumab had a good result when CRP levels were $\geq 100 \mathrm{mg} / \mathrm{L}$ and $\mathrm{P} / \mathrm{F}$ ratio was 200-300 $\mathrm{mmHg}$ or $<200 \mathrm{mmHg}$. Administration of tocilizumab for CRP levels $<100 \mathrm{mg} / \mathrm{L}$ did not reduce mortality and showed a longer length of stay in hospital.

There are various types of administration of tocilizumab treatment among studies. Tocilizumab can be administrated at a low dose (400 mg or $4 \mathrm{mg} / \mathrm{kg}$ ) or high dose ( $800 \mathrm{mg}$ or $8 \mathrm{mg} / \mathrm{kg}$ ), as a single-dose and then continue with the second dose if clinical condition worsens in 24 hours (maximum $800 \mathrm{mg}$ per dose), intravenously or subcutaneously.

\section{Strengths and limitations of the analysis}

Meta-analysis on this topic has not been previously conducted; only mortality events and ICU admissions have been reported by previous studies ${ }^{9-11,13}$. In our study, we evaluate all-cause mortality events, length of stay in hospital, and days until death (time to death after first intervention) and carry out subgroup analysis of baseline criteria for administration of tocilizumab treatment. This study has a larger sample size; 2112 patients in the tocilizumab group and 6160 patients in the SOC group.

The limitations of this study are that we didn't perform subgroup analysis outcomes according to the dosage and route of administration tocilizumab and didn't analyze secondary outcomes after tocilizumab treatment like bacterial or fungal infections, thrombotic events, major bleeding, or requirement of invasive mechanical ventilation requirement. The results of our study should be used carefully because most studies included were retrospective and only two were randomized clinical trials, since it has been difficult to perform randomized trial during this pandemic. A meta-analysis of more clinical trial data will provide a more precise result for tocilizumab treatment in severe and critically ill COVID-19 patients.

\section{Conclusion}

Our study provides meaningful data regarding the effect of tocilizumab in severe and critically ill confirmed COVID-19 


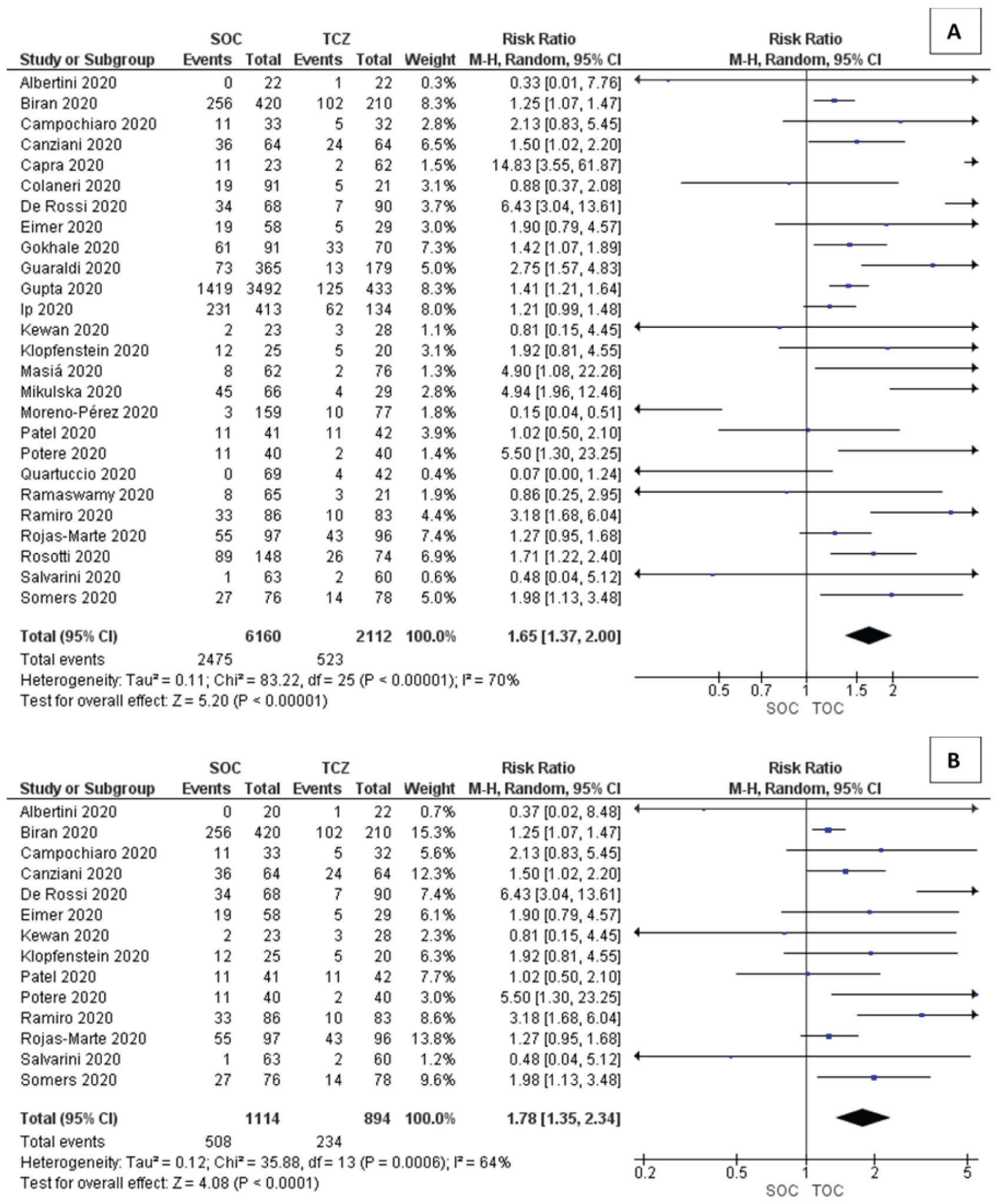




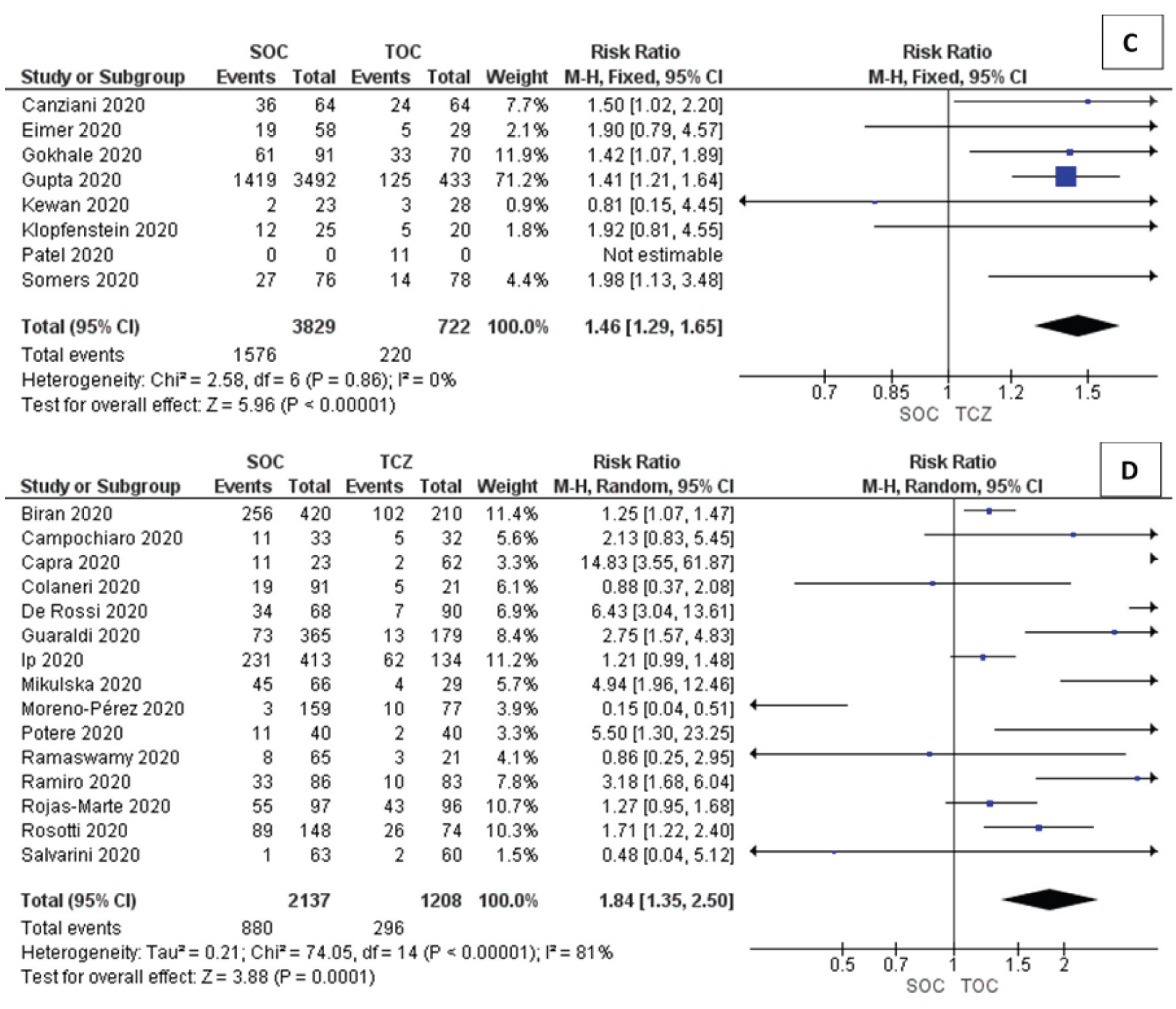

Figure 2. Forest plot outcome between SOC group and TCZ group. A) All-cause mortality event; B) Subgroup CRP >100 mg/L; C) Subgroup PaO2:FiO2 200-300 mmHg; D) Subgroup PaO2:FiO2 <200 mmHg. SOC, standard of care; TCZ, tocilizumab; CRP, C-reactive protein; SD, standard deviation; CI, confidence intervals.

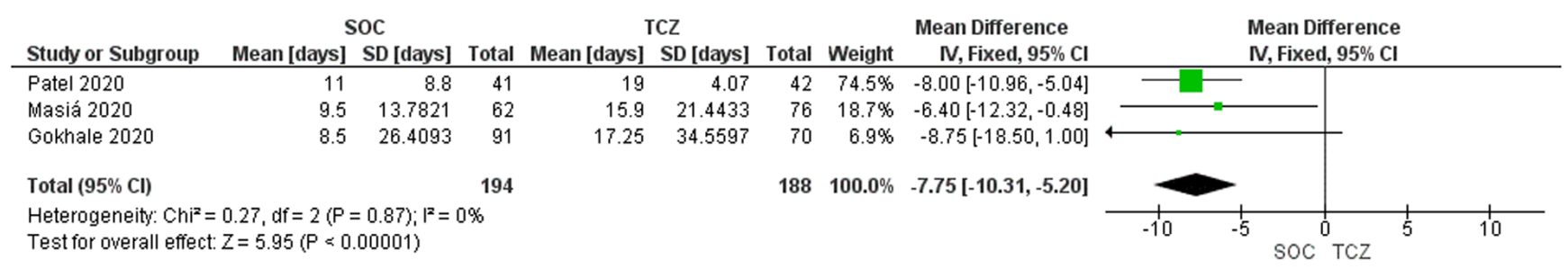

Figure 3. A forest plot length of stay baseline criteria for administration of tocilizumab CRP $<100 \mathrm{mg} / \mathrm{L}$. SOC, standard of care; TCZ, tocilizumab; CRP, C-reactive protein; SD, standard deviation; CI, confidence intervals.

patients. Tocilizumab is a treatment option for severe and critically ill COVID-19 patients and it appears to reduce mortality events, especially when CRP level $>100 \mathrm{mg} / \mathrm{L}, \mathrm{P} / \mathrm{F}$ ratio
200-300 $\mathrm{mmHg}$, and $\mathrm{P} / \mathrm{F}$ ratio $<200 \mathrm{mmHg}$. However, tocilizumab should be used cautiously according to proper selection criteria to achieve optimal results and its use should be tailored 
according to the eligibility of the patients. Further studies are still required, especially regarding optimal dosage and administration route of tocilizumab in COVID-19 patients.

\section{Data availability}

Underlying data

Figshare: Data systematic review and meta-analysis optimal use tocilizumab.zip. https://doi.org/10.6084/m9.figshare.13655894.v116.

This project contains the following underlying data:

$$
\text { TCZ_for_COVID-19.csv9 }
$$

\section{Extended data}

Figshare: Data systematic review and meta-analysis optimal use tocilizumab.zip. https://doi.org/10.6084/m9.figshare.13655894.v1 ${ }^{16}$.
This project contains the following extended data:

PubMed and Cochrane search strategies (in JPG format)

Reporting guidelines

Figshare: PRISMA checklist for "Optimal use of tocilizumab for severe and critical COVID-19: a systematic review and metaanalysis". https://doi.org/10.6084/m9.figshare.13655894.v1 ${ }^{16}$.

Data are available under the terms of the Creative Commons Attribution 4.0 International license (CC-BY 4.0).

\section{Acknowledgments}

We are here to thank Prof. Dr. dr. Nasronudin, Sp. PD K-PTI for supporting us in completing this study.
1. Huang C, Wang Y, Li X, et al.: Clinical features of patients infected with 2019 novel coronavirus in Wuhan, China. Lancet. 2020; 395(10223): 497-506. PubMed Abstract | Publisher Full Text | Free Full Text

2. Ye Q, Wang B, Mao J: The pathogenesis and treatment of the 'Cytokine Storm' in COVID-19. J Infect. 2020; 80(6): 607-613.

PubMed Abstract | Publisher Full Text | Free Full Text

3. Rahmati M: Cytokine-targeted therapy in severely ill CovID-19 patients: Options and cautions. Eurasian J Med Oncol. 2020; 4(2): 179-181. Publisher Full Text

4. Garg S, Garg M, Prabhakar N, et al.: Unraveling the mystery of Covid-19 cytokine storm: From skin to organ systems. Dermatol Ther. 2020; 33(6): e13859.

PubMed Abstract | Publisher Full Text | Free Full Text

5. Moore JB, June $\mathrm{CH}$ : Cytokine release syndrome in severe COVID-19. Science. 2020; 368(6490): 473-474.

PubMed Abstract | Publisher Full Text

6. Zhang C, Wu Z, Li JW, et al:: Cytokine release syndrome in severe COVID-19: interleukin- 6 receptor antagonist tocilizumab may be the key to reduce mortality. Int J Antimicrob Agents. 2020; 55(5): 105954

PubMed Abstract | Publisher Full Text | Free Full Text

7. Luo $\mathrm{P}$, Liu $\mathrm{Y}$, Qiu L, et al.: Tocilizumab treatment in COVID-19: A single center experience. J Med Virol. 2020; 92(7): 814-818. PubMed Abstract | Publisher Full Text | Free Full Tex

8. $\mathrm{Xu} X, \mathrm{Han} \mathrm{M}, \mathrm{Li}$ T, et al.: Effective treatment of severe COVID-19 patients with tocilizumab. Proc Natl Acad Sci U S A. 2020; 117(20): 10970-10975.

PubMed Abstract | Publisher Full Text | Free Full Text

9. Zhao J, Cui W, Tian BP: Efficacy of tocilizumab treatment in severely ill COVID-19 patients. Crit Care. 2020; 24(1): 524.

PubMed Abstract | Publisher Full Text | Free Full Text

10. Lan SH, Lai CC, Huang HT, et al:: Tocilizumab for severe COVID-19: a systematic review and meta-analysis. Int J Antimicrob Agents. 2020; 56(3): 106103

PubMed Abstract | Publisher Full Text | Free Full Text

11. Kaye AG, Siegel R: The Efficacy of IL-6 Inhibitor Tocilizumab in Reducing Severe COVID-19 Mortality: A Systematic Review. medRxiv. 2020. Publisher Full Text

12. Mojtabavi H, Saghazadeh A, Rezaei N: Interleukin-6 and severe COVID-19: a systematic review and meta-analysis. Eur Cytokine Netw. 2020; 31(2): 44-49. PubMed Abstract | Publisher Full Text | Free Full Text

13. Zhao M, Lu J, Tang Y, et al.: Tocilizumab for treating COVID-19: a systemic review and meta-analysis of retrospective studies. Eur J Clin Pharmacol. 2020; 1 -9.

PubMed Abstract | Publisher Full Text | Free Full Text

14. Rohman MS, Purnamasari Y, Ilmawan M, et al.: Comparison of major bleeding in patients with acute coronary syndrome that underwent coronary artery bypass grafting treated with clopidogrel or ticagrelor: a systematic review and meta-analysis [version 2; peer review: 1 approved, 1 approved with reservations]. F1000Res. 2020; 9: 99.

Publisher Full Text

15. McInnes MDF, Moher $D$, Thombs $B D$, et al.: Preferred Reporting Items for a Systematic Review and Meta-analysis of Diagnostic Test Accuracy Studies: The PRISMA-DTA Statement. JAMA. 2018; 319(4): 388-396.

PubMed Abstract | Publisher Full Text

16. Suryantoro SD: Data systematic review and meta-analysis optimal use tocilizumab.zip. figshare. Journal contribution. 2021 http://www.doi.org/10.6084/m9.figshare.13655894.v

17. Stang A: Critical evaluation of the Newcastle-Ottawa scale for the assessment of the quality of nonrandomized studies in meta-analyses. Eur | Epidemiol. 2010; 25(9): 603-5.

PubMed Abstract | Publisher Full Text

18. Albertini $L$, Soletchnik $M$, Razurel $A$, et al.: Observational study on off-label use of tocilizumab in patients with severe COVID-19. Eur J Hosp Pharm 2021: 28(1): 22-27.

PubMed Abstract | Publisher Full Text | Free Full Text

19. Biran N, Ip A, Ahn J, et al.: Tocilizumab among patients with COVID-19 in the intensive care unit: a multicentre observational study. Lancet Rheumatol. 2020; 2(10): e603-e612.

PubMed Abstract | Publisher Full Text | Free Full Text

20. Campochiaro C, Della-Torre E, Cavalli G, et al.: Efficacy and safety of tocilizumab in severe COVID-19 patients: a single-centre retrospective cohort study. Eur J Intern Med. 2020; 76: 43-49. PubMed Abstract | Publisher Full Text | Free Full Text

21. Canziani LM, Trovati S, Brunetta E, et al.: Interleukin-6 receptor blocking with intravenous tocilizumab in COVID-19 severe acute respiratory distress syndrome: A retrospective case-control survival analysis of 128 patients. J Autoimmun. 2020; 114: 102511.

PubMed Abstract | Publisher Full Text | Free Full Text

22. Capra R, De Rossi N, Mattioli F, et al.: Impact of low dose tocilizumab on mortality rate in patients with COVID-19 related pneumonia. Eur J Intern Med. 2020; 76: 31-35.

PubMed Abstract | Publisher Full Text | Free Full Text

23. Colaneri M, Bogliolo L, Valsecchi P, et al.: Tocilizumab for Treatment of Severe COVID-19 Patients: Preliminary Results from SMAtteo COvid19 REgistry (SMACORE). Microorganisms. 2020; 8(5): 695.

PubMed Abstract | Publisher Full Text | Free Full Text

24. De Rossi N, Scarpazza C, Filippini C, et al.: Early use of low dose tocilizumab in patients with COVID-19: A retrospective cohort study with a complete follow-up. EClinicalMedicine. 2020; 25: 100459.

PubMed Abstract | Publisher Full Text | Free Full Text

25. Eimer J, Vesterbacka J, Svensson AK, et al.: tocilizumab shortens time on mechanical ventilation and length of hospital stay in patients with severe COVID-19: a retrospective cohort study. J Intern Med. 2020.

PubMed Abstract | Publisher Full Text | Free Full Text

26. Gokhale $\mathrm{Y}$, Mehta R, Karnik N, et al.: Tocilizumab improves survival in patients with persistent hypoxia in severe COVID-19 pneumonia. 
EClinicalMedicine. 2020; 24: 100467.

PubMed Abstract | Publisher Full Text | Free Full Text

27. Guaraldi G, Meschiari M, Cozzi-Lepri A, et al.: Tocilizumab in patients with severe COVID-19: a retrospective cohort study. Lancet Rheumatol. 2020; 2(8): e474-e84.

PubMed Abstract | Publisher Full Text | Free Full Text

28. Gupta S, Wang W, Hayek SS, et al:: Association Between Early Treatment With Tocilizumab and Mortality Among Critically Ill Patients With COVID19. JAMA Intern Med. 2021; 181(1): 41-51.

PubMed Abstract | Publisher Full Text | Free Full Text

29. Ip $A$, Berry $D A$, Hansen $E$, et al.: Hydroxychloroquine and tocilizumab therapy in COVID-19 patients-An observational study. PLOS One. 2020; 15(8): e0237693.

PubMed Abstract | Publisher Full Text | Free Full Text

30. Kewan T, Covut F, Al-Jaghbeer MJ, et al: Tocilizumab for treatment of patients with severe COVID-19: A retrospective cohort study. EClinicalMedicine. 2020; 24: 100418.

PubMed Abstract | Publisher Full Text | Free Full Text

31. Klopfenstein $\mathrm{T}$, Zayet $\mathrm{S}$, Lohse $\mathrm{A}$, et al.: Tocilizumab therapy reduced intensive care unit admissions and/or mortality in COVID-19 patients. Med Mal Infect. 2020; 50(5): 397-400.

PubMed Abstract | Publisher Full Text | Free Full Text

32. Masiá M, Fernández-González M, Padilla S, et al.: Impact of interleukin-6 blockade with tocilizumab on SARS-CoV-2 viral kinetics and antibody responses in patients with COVID-19: A prospective cohort study. EBioMedicine 2020: 60: 102999

PubMed Abstract | Publisher Full Text | Free Full Text

33. Mikulska M, Nicolini LA, Signori A, et al:: Tocilizumab and steroid treatment in patients with COVID-19 pneumonia. PLoS One. 2020; 15(8): e0237831. PubMed Abstract | Publisher Full Text | Free Full Text

34. Moreno-Pérez O, Andres M, Leon-Ramirez JM, et al.: Experience with tocilizumab in severe COVID-19 pneumonia after $\mathbf{8 0}$ days of follow-up: A retrospective cohort study. J Autoimmun. 2020; 114: 102523. PubMed Abstract | Publisher Full Text | Free Full Text

35. Patel K, Gooley TA, Bailey N, et al.: use of the IL-6R antagonist tocilizumab in hospitalized COVID-19 patients. JIntern Med. 2020.

PubMed Abstract | Publisher Full Text | Free Full Text
36. Potere N, Di Nisio M, Rizzo G, et al.: Low-dose subcutaneous tocilizumab to prevent disease progression in patients with moderate COVID-19 pneumonia and hyperinflammation. Int I Infect Dis. 2020; 100: 421-424. PubMed Abstract | Publisher Full Text | Free Full Text

37. Quartuccio L, Sonaglia A, McGonagle D, et al.: Profiling CoviD-19 pneumonia progressing into the cytokine storm syndrome: Results from a single Italian Centre study on tocilizumab versus standard of care. J Clin Virol. 2020: 129: 104444

PubMed Abstract | Publisher Full Text | Free Full Text

38. Ramaswamy M, Mannam P, Comer R, et al.: Off-Label Real World Experience Using Tocilizumab for Patients Hospitalized with COVID-19 Disease in a Regional Community Health System: A Case-Control Study, medRxiv. 2020. Publisher Full Text

39. Ramiro S, Mustard RLM, Magro-Checa C, et al.: Historically controlled comparison of glucocorticoids with or without tocilizumab versus supportive care only in patients with COVID-19-associated cytokine storm syndrome: results of the CHIC study. Ann Rheum Dis. 2020; 79(9): 1143-1151. PubMed Abstract | Publisher Full Text | Free Full Text

40. Rojas-Marte G, Khalid M, Mukhtar O, et al:: Outcomes in patients with severe COVID-19 disease treated with tocilizumab: a case-controlled study. $Q / M$. 2020; 113(8): 546-550.

PubMed Abstract | Publisher Full Text | Free Full Text

41. Rossotti R, Travi G, Ughi N, et al.: Safety and efficacy of anti-il6-receptor tocilizumab use in severe and critical patients affected by coronavirus disease 2019: A comparative analysis. J Infect. 2020; 81(4): e11-e17. PubMed Abstract | Publisher Full Text | Free Full Text

42. Salvarani C, Dolci G, Massari M, et al.: Effect of Tocilizumab vs Standard Care on Clinical Worsening in Patients Hospitalized With COVID-19 Pneumonia: A Randomized Clinical Trial. JAMA Intern Med. 2020; 181(1): 24-31. PubMed Abstract | Publisher Full Text | Free Full Text

43. Somers EC, Eschenauer GA, Troost JP, et al.: Tocilizumab for treatment of mechanically ventilated patients with COVID-19. medRxiv. 2020. PubMed Abstract | Publisher Full Text | Free Full Text

44. Patel U, Xie JJ, Palmer Q, et al:: An Extraordinary Case of Extranodal NonHodgkin's Lymphoma Presenting as Common Bile Duct Mass. J Gastrointest Cancer. 2020; 51(1): 359-362.

PubMed Abstract | Publisher Full Text 


\section{Open Peer Review}

\section{Current Peer Review Status: $\checkmark$ ? ?}

\section{Version 1}

Reviewer Report 11 March 2021

https://doi.org/10.5256/f1000research.48118.r81031

(c) 2021 Zhang Z. This is an open access peer review report distributed under the terms of the Creative Commons Attribution License, which permits unrestricted use, distribution, and reproduction in any medium, provided the original work is properly cited.

\section{Zhongheng Zhang}

Department of Emergency Medicine, Sir Run Run Shaw Hospital, Zhejiang, China

This meta-analysis can provide updated evidence for an important clinical question; However, I have several comments:

1. The authors combined evidence from RCT and observational studies, which is not appropriate; the authors need to at least perform subgroup (sensitivity) analysis by restricting only high-quality trials.

2. Bayesian meta-analysis may be appropriate for down-weighing observational studies.

3. Most studies are small in sample size; the limitation of small study effect should be addressed and discussed; this effect has been well characterized in literature (Zhang et al., $2013^{1}$ ).

4. Many observational studies may include adjusted effect size, try to combine this adjusted $\mathrm{OR}(\mathrm{RR})$ and to see whether this will change the current conclusion.

5. Many interventional meta-analysis on COVID-19 have been published in the literature (Kim et al., 20202, Aziz et al., 202133, Zhao et al., 2020 and Kotak et al., 20205); the authors need to clarify how their study can add to the existing literature.

\section{References}

1. Zhang Z, Xu X, Ni H: Small studies may overestimate the effect sizes in critical care metaanalyses: a meta-epidemiological study.Crit Care. 2013; 17 (1): R2 PubMed Abstract | Publisher Full Text

2. Kim MS, An MH, Kim WJ, Hwang TH: Comparative efficacy and safety of pharmacological interventions for the treatment of COVID-19: A systematic review and network meta-analysis.PLoS Med. 17 (12): e1003501 PubMed Abstract | Publisher Full Text

3. Aziz M, Haghbin H, Abu Sitta E, Nawras Y, et al.: Efficacy of tocilizumab in COVID-19: A systematic review and meta-analysis.J Med Virol. 93 (3): 1620-1630 PubMed Abstract | Publisher Full Text 
4. Zhao J, Cui W, Tian B: Efficacy of tocilizumab treatment in severely ill COVID-19 patients. Critical Care. 2020; 24 (1). Publisher Full Text

5. Kotak S, Khatri M, Malik M, Malik M, et al.: Use of Tocilizumab in COVID-19: A Systematic Review and Meta-Analysis of Current Evidence.Cureus. 2020; 12 (10): e10869 PubMed Abstract | Publisher Full Text

Are the rationale for, and objectives of, the Systematic Review clearly stated?

Yes

Are sufficient details of the methods and analysis provided to allow replication by others? Yes

Is the statistical analysis and its interpretation appropriate? Partly

Are the conclusions drawn adequately supported by the results presented in the review? Partly

Competing Interests: No competing interests were disclosed.

Reviewer Expertise: critical care medicine

I confirm that I have read this submission and believe that I have an appropriate level of expertise to confirm that it is of an acceptable scientific standard, however I have significant reservations, as outlined above.

Author Response 12 Mar 2021

Satriyo Dwi Suryantoro

We would like to firstly express our gratitude for having our manuscript reviewed thoroughly.

Best regards,

Research team.

Competing Interests: We have no conflict of interest

Reviewer Report 02 March 2021

https://doi.org/10.5256/f1000research.48118.r79722

(C) 2021 Wiyono W. This is an open access peer review report distributed under the terms of the Creative Commons Attribution License, which permits unrestricted use, distribution, and reproduction in any medium, provided the original work is properly cited. 


\section{Wiwien Heru Wiyono}

Department of Pulmonology and Respiratory Medicine, Universitas Indonesia, Jakarta, Indonesia

\section{1) Data extraction and quality assessment:}

Two independent investigators conducted the study assessment (BAM and CW). Two authors (BAM and EA) extracted necessary data.

I think it is not necessary to inform that one acts as an independent investigator, while he is also a member of the authors who extracted the data. Its independence is questionable.

\section{2) Conclusion:}

Tocilizumab is a treatment option for severe and critically ill COVID-19 patients and it appears to reduce mortality events, especially when CRP level $>100 \mathrm{mg} / \mathrm{L}, \mathrm{P} / \mathrm{F}$ ratio $200-300 \mathrm{mmHg}$, and P/F ratio $<200 \mathrm{mmHg}$.

1. The authors did not explain in the discussion that $\mathrm{P} / \mathrm{F}$ ratio $200-300 \mathrm{mmHg}$ and $\mathrm{P} / \mathrm{F}$ ratio < $200 \mathrm{mmHg}$ is actually different in mode.

2. When the mode of both variables is ignored, why not just conclude: when P/F ratio $<300$ $\mathrm{mm} \mathrm{Hg}$.

3. Clinicians need clear conclusions, the authors' conclusions about P/F ratio $200-300 \mathrm{mmHg}$ and $\mathrm{P} / \mathrm{F}$ ratio $<200 \mathrm{~mm} \mathrm{Hg}$ are confusing.

Are the rationale for, and objectives of, the Systematic Review clearly stated? Yes

Are sufficient details of the methods and analysis provided to allow replication by others? Yes

Is the statistical analysis and its interpretation appropriate?

Yes

Are the conclusions drawn adequately supported by the results presented in the review? Partly

Competing Interests: No competing interests were disclosed.

Reviewer Expertise: Clinical Pulmonology

I confirm that I have read this submission and believe that I have an appropriate level of expertise to confirm that it is of an acceptable scientific standard, however I have significant reservations, as outlined above.

Author Response 03 Mar 2021

Satriyo Dwi Suryantoro

Dear Prof. Wiwien, 
1) Thank you for the helpful and considerate advices.

2) To all intents and purposes, in this research we didn't particularly examine and conclude the effect of TCZ on P/F ratio less than 300, yet we figured out significantly good impact/effect of TCZ on patients with mild ARDS (P/F ratio $200-300 \mathrm{mmHg}$ ), as we have mentioned on page 9 of the manuscript.

Competing Interests: There is no financial competing interest. We hope to benefit as a result of our submission for further treatment COVID-19 using Tocilizumab.

Reviewer Report 05 February 2021

https://doi.org/10.5256/f1000research.48118.r78921

(C) 2021 Cosmi L. This is an open access peer review report distributed under the terms of the Creative Commons Attribution License, which permits unrestricted use, distribution, and reproduction in any medium, provided the original work is properly cited.

\section{Lorenzo Cosmi}

Department of Experimental and Clinical Medicine, University of Florence, Florence, Italy

The manuscript "Optimal use of tocilizumab for severe and critical COVID-19: a systematic review and meta-analysis", is an exhaustive meta-analysis on studies that have evaluated the efficacy of treatment with tocilizumab in COVID-19. The meta-analysis is well performed, and the results are convincing and in line with the real life evidences, which suggest an efficacy of such a treatment in selected patients. The authors correctly underline that the treatment works in patients with high inflammatory status and with impairment of respiratory function (P/F ratio below than $300 \mathrm{~mm}$ $\mathrm{Hg}$ ). The concept that tocilizumab improves the prognosis of severe COVID-19 patients, reducing hyper inflammation that contributes to vascular pulmonary damage is an important message for the scientific community.

I have no particular concerns on this manuscript. I only suggest to quote in the introduction also a recent paper that focuses on the ability of tocilizumab to improve the lung perfusion in these patients (Salvati et al., 2020¹).

\section{References}

1. Salvati L, Occhipinti M, Gori L, Ciani L, et al.: Pulmonary vascular improvement in severe COVID19 patients treated with tocilizumab.Immunol Lett. 228: 122-128 PubMed Abstract | Publisher Full Text

Are the rationale for, and objectives of, the Systematic Review clearly stated? Yes

Are sufficient details of the methods and analysis provided to allow replication by others? 
Yes

Is the statistical analysis and its interpretation appropriate?

Yes

Are the conclusions drawn adequately supported by the results presented in the review? Yes

Competing Interests: No competing interests were disclosed.

Reviewer Expertise: COVID-19

I confirm that I have read this submission and believe that I have an appropriate level of expertise to confirm that it is of an acceptable scientific standard.

The benefits of publishing with F1000Research:

- Your article is published within days, with no editorial bias

- You can publish traditional articles, null/negative results, case reports, data notes and more

- The peer review process is transparent and collaborative

- Your article is indexed in PubMed after passing peer review

- Dedicated customer support at every stage

For pre-submission enquiries, contact research@f1000.com

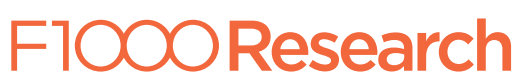

